\title{
Survey of Major Insect Pests, Uses of Management Practices and Other Related Information of Sugarcane (Saccharum officinarum L.) Growers of the Northern Region of Bangladesh
}

\author{
Md. Abdul Ahad ${ }^{1}$, Ruji Raihana Ferdaus ${ }^{1}$, Md. Rezaul Ahsan², Md. Muzammel Hoque ${ }^{3}$, \\ A. N. M. Safiqul Islam 4 \\ ${ }^{1}$ Department of Entomology, Hajee Mohamed Danesh Science and Technology University, Dinajpur, Bangladesh \\ ${ }^{2}$ Finance Division, Ministry of Finance, Bangladesh Secretariat, Bangladesh \\ ${ }^{3}$ National Scientific and Technical Documentation Center (BANSDOC), E-14/Y, Agargaon, Dhaka, Bangladesh \\ ${ }^{4}$ Kaliakoir Hi-Tech Park Project Bangladesh, Hi-Tech Park Project Authority, BCC Bhaban, Sher-E-Bangla Nagar, Dhaka, Bangladesh
}

\section{Email address:}

maahad@hstu.ac.bd (Md. A. Ahad), maahadhstu@gmail.com (Md. A. Ahad)

\section{To cite this article:}

Md. Abdul Ahad, Ruji Raihana Ferdaus, Md. Rezaul Ahsan, Md. Muzammel Hoque, A. N. M. Safiqul Islam. Survey of Major Insect Pests, Uses of Management Practices and Other Related Information of Sugarcane (Saccharum officinarum L.) Growers of the Northern Region of Bangladesh. American Journal of Life Sciences. Vol. 3, No. 6, 2015, pp. 408-411. doi: 10.11648/j.ajls.20150306.15

\begin{abstract}
Kantajir sugarcane Farm is the largest farm that situated a Kharol thana, Dinajprur, Bangladesh. There are 140.08 hectares (346 acres) of land. Farmers of the adjacent locality received leased of that land and cultivate sugarcane. Data collected from those farmers (5o farmers) during 01.01.12 to 31.03.12 from Sunderbon union of that Thana. Farmers informed that stem borer (Chilo tumidicostalis), early shoot borer (Chilo infuscatellus), top shoot borer (Scirpophaga incertulus), root borer (Emmalocera depressela), termite (Odontotermies obsesus), mealy bug (Sacchariccous sacchari) and scale insect (Melanapis glomerata) were major pest, respectively; even after application of insecticides (Furadan 5G). Moreover, 77.27\% farmers informed that they used only Furadan 5G for the control of all type of stem borers; $54.54 \%$ farmers informed that they used losburn for control of termite. But removal of stem borer infested plant parts and killing of early shoot borer larvae by removal of soil was followed $21 \%$ farmers. In addition, the highest $77.27 \%$ farmers were acknowledged that those received information from the 'Sugarcane development assistance' followed by 'Center in charge (13.63\%). Additionally, $814.82 \%$ farmers said that they cultivated Isd 37 sugarcane variety followed by Isd-21 (40.91\% farmers), and Isd 26 (27.27\% farmers). Furthermore, $63.63 \%$ farmers informed that those cultivated chili Capsicum annuum as relay crops followed by potato Solanum tuberosum $54.54 \%$ (farmers), tomato Solanum lycopersicum 18.18\% (farmers) and cucumber Cucumis sativus $13.63 \%$ (farmers). Moreover, farmers obtained every inputs such as sugarcane set (seeds), fertilizer and insecticide as loan and those loans were paid during the selling of sugarcane to the mill of Shetabgonj (Dinajpur, Bangladesh). In addition, those farmers claimed that they suffered various problems for sugarcane cultivation such as lack of marketing facilities (late purchase of sugarcane by the sugarcane mill, when it reduced its weight due do dry) and stem borer insect infestation.
\end{abstract}

Keywords: Insect Pest, Insecticides, Mechanical Control, Sugarcane Variety, Relay Crops, Problems

\section{Introduction}

Sugarcane (Saccharum officinarum L.) is one of the most important cash-cum-industrial crops in Bangladesh [1, 2, and 3]. It is the second sugar producing crop of the world but in Bangladesh it rank is first [4]. The average yield of sugarcane in Bangladesh is very low compared to other sugarcane growing countries [5]. For example, it is 42.0 t/ha in Bangladesh [6]. Whereas, in India 56.0 t/ha [7]. Additionally, insect pests alone cause damage ranging from 20-60\% [8]. Among various factors of yield reducing; insect pests inflicts considerable losses, which are estimated to be around $20 \%$ in cane yield and $15 \%$ in sugar recovery [5]. However, so far about 70 species of the insect pests have been identified to feed on sugarcane in Bangladesh $[9,10]$. It is also reported that the most important pests of 
sugarcane are: i) early shoot borer, ii) top shoot borer, iii) stem borer, iv) rootstock borer v) mealy bug, and vi) scale insect and vii) white grubs. The yield losses due to those insect pests were estimated to be $22-33 \%$ by early shoot borer [11]; $21-48 \%$ by top shoot borer [12]; $8.2-12.6 \%$ by stem borer [13]; and $8.55-10 \%$ by root stock borer [14]; 1 . $43 \%$ by scale insect [13], $24.1 \%$ by mealy bug and $23.07-$ $38.17 \%$ by white grubs [15]. Various techniques such as cultural, mechanical, biological and chemical methods have been recommended to control those pests [16].

An understanding of insect pest attack and the associated factors would be helpful to planners and extension workers to devise strategies and courses of actions for effective control of the insect pests [17] (Ahad and Haque, 1993).

However, there are two sugar mills in this area: one is Thakurgaon sugar mill and another is Shetabgonj at Dinajpur. The raw materials of sugar (sugarcane) are supplied from those two mills. So, sugarcane is very important crop of this area.

But literatures reveal that information about major insect pests and other problems related to sugarcane (Saccharum officinarum L.) Cultivation is about scanty, especially in Bangladesh. However, Ahad and Haque [17] conducted a research on the insect pests faced by the farmers in sugarcane cultivation in Bangladesh. But it does not fulfill the overall need. Consequently, a research program was under taken whose objectives are: i) to know different insect pests of sugarcane, ii) different problems faced by sugarcane growers, iii) pest management practice they use, iv) the different verities of sugarcane they cultivate, v) different sources they use to take advice for management of insect pests and other purposes, vi) their sources of loan, and finally vii) to know the relay crops they cultivate.

The research would be helpful to the researchers such as to agriculturists, entomologists, agriculture extortionists, sociologists, psychologists and also those who are interested to conducte a research based on interview schedule.

\section{Materials and Methods}

The methodology was followed according to Ahad and Haque [17] and Ahad et. al. [18]. Based on the literature, it was first surveyed how many insect pests attacked in the sugarcane crop in Bangladesh and India. Based on those data, an interview schedules was set for the collection of required data that mention in the objectives. A colour photograph (laminated) also prepared about the nature of damage and the insect pests of sugarcane. Then, it showed to the farmers and explains clearly and then asked those farmers, whether those insect pests are major, minor or absent. Besides, other questions (those mentioned in the objectives) were also asked. Finally, the obtained data were converted into percentages and compiled in various tables for illustration in the result and discussions.

\section{Results and Discussions}

\subsection{Major Insect Pests of Sugarcane}

Seven insect species were noted to attack sugarcane. However, $90.50 \%$ farmers claimed that sugarcane stem borer (Chailo tumidicostalis) was a serious insect pest. Whereas $40.98,40.98,50.48,17.80,20.50,7.30$ and $25.20 \%$ farmers (Table-1) claimed that sugarcane early borer $(C$. infuscatellus), termite (Odontotermies obsesus), mealybug (Sacchariccous sacchari), scale insect (Melanapis glomerata) were damaged sugarcane crop, respectively. Consequently, those were major pest, respectively. It was seen that major $\%$ of farmers claimed that sugarcane stem borer was the major pests. So, stem borer was the serious pest even after application of insecticides. But insecticides reduced the damaged of sugarcane early borer $(C$. infuscatellus), termite (Odontotermies obsesus) scale insect and mealy bug. Patil and Hapase [21], Ahad et al. [2], Ahad [3] reported that the most important pests of sugarcane were early shoot borer, top shoot borer, stem borer, rootstock borer, mealy bug, scale insect and white grubs, which more or less supports the result of the present study.

Table 1. Comments of sugarcane farmers (\%) about major insect pests.

\begin{tabular}{|c|c|c|c|c|}
\hline \multirow[t]{2}{*}{ Insect pests } & \multirow[t]{2}{*}{ Family } & \multicolumn{3}{|c|}{$\begin{array}{l}\text { Comments of farmers } \\
\text { (\%) about infestation of } \\
\text { major/minor insect pests }\end{array}$} \\
\hline & & Major & Minor & $\begin{array}{l}\text { Not } \\
\text { found }\end{array}$ \\
\hline $\begin{array}{l}\text { i) Sugarcane Stem borer } \\
\text { (Chailo tumidicostalis) * }\end{array}$ & Pyralidae & 90.50 & 9.50 & 0.0 \\
\hline $\begin{array}{l}\text { ii) Sugarcane top shoot borer } \\
\text { (Scirpophaga incertulus) }\end{array}$ & Pyralidae & 40.98 & 54.57 & 4.45 \\
\hline $\begin{array}{l}\text { iii)Sugarcane early borer ( } C \text {. } \\
\text { infuscatellus) }\end{array}$ & Pyralidae & 50.48 & 47.02 & 2.50 \\
\hline $\begin{array}{l}\text { iv) Sugercane root borer } \\
\text { (Emmalocera depressela) }\end{array}$ & Pyralidae & 17.80 & 18.08 & 36.36 \\
\hline $\begin{array}{l}\text { v) Termite (Odontotermies } \\
\text { obsesus) }\end{array}$ & Termitidae & 20.50 & 45.45 & 47.02 \\
\hline $\begin{array}{l}\text { vi) Scale insect (Melanapis } \\
\text { glomerata) }\end{array}$ & Coccidae & 7.30 & 42.24 & 50.46 \\
\hline $\begin{array}{l}\text { vii) Mealy bug mealybug } \\
\text { (Sacchariccous sacchari) }\end{array}$ & Pseudococcidae & 25.20 & 52.46 & 27.26 \\
\hline
\end{tabular}

*Serious pest.

\subsection{Use of Insecticides and Other Management Practices Used by the Sugarcane Farmers}

Farmers used seven types of insecticide but total $77.27 \%$ (highest $\%$ ) farmers used Furadan $5 \mathrm{G}$ insecticide followed by Loss burn (54.54\%), Ad furan (13.63\%), and Briefer $(9.09 \%)$, Karate $(9.09 \%)$, lime $(9.09 \%)$, respectively (able 2$)$. Ahad et al. [4] showed that sugarcane farmers mainly use Furadan $5 \mathrm{G}$ for the control about all insect pest and Heptachlor for the control of termite. Here farmers use Loss burn instead of Heptachlor, as it is banned by the government of Bangladesh. This result supports the result of the present research. In addition, total $72.72 \%$ farmers remove the infested sugarcane shoot borer, stems and thrown into the water; killing of early shoot borer larvae by removal of soil is 
also done by some farmers i. e. they use mechanical method of pest control (Table-2).

Table 2. Use of insecticides and other management practices used by the sugarcane farmers.

\begin{tabular}{ll}
\hline Insecticides & \% Farmers use \\
\hline Furadan 5G (Carbofuran) & 77.27 \\
Lorsban (Clorpyrephos group) & 54.54 \\
Agrofuran (Carbofuran group) & 13.63 \\
Brefer(Carbofuran group) & 9.09 \\
Karata(Carbofuran group) & 4.44 \\
Azodrin (organophosphorus) & 4.44 \\
Lime & 4.44 \\
Avastan (Fungicide) & 40.05 \\
Others management practices & \\
Removal of insect infested sugarcane by stem borer & 72.72 \\
and it was thrown into the water & \\
Killing of early shoot borer larvae by removal of soil & $31 \%$ \\
\hline
\end{tabular}

\subsection{Use of Source Advice for the Insect Pest Control}

It was observed that farmers took advice for management of sugarcane pest mainly from the cane development assistance $(77.27 \%)$ followed by Center in charge (13.63\%), own experience $(9.09 \%)$, friends $(9.09 \%)$, Assistant manager $(9.09 \%)$, SCI $(9.09 \%)$ and relatives $(04.45 \%)$, respectively (Table - 3).

Table 3. Percentages of sources of information for advice for the control of sugarcane pests.

\begin{tabular}{ll}
\hline Sources of advice (information) & Farmer (\%) \\
\hline Cane development assistance (CDA) & 77.27 \\
CIC (Center in charge) & 13.63 \\
Self (use own experience) & 9.09 \\
Relatives and friends & 4.45 \\
SACDO (Sub-assistance cane development officer) & 9.09 \\
AM (Assistant manager) & 9.09 \\
Insecticides dealers & 4.45 \\
\hline
\end{tabular}

\subsection{Sugarcane Variety Cultivated in Dinajpur}

Farmers were cultivated mainly five varieties of sugarcane such as Isd 37, Isd 21 Isd 26 Isd 33, Isd 39. But most farmers cultivate Isd $37(81.82 \%$ farmers $)$ followed by Isd 21
(40.91\% farmers), Isd 26 (27.27\% farmers), Isd 33(13.36\% farmers) and Isd 39(13.36\% farmers). As a result, those were popular varieties, respectively. Moreover, Isd 12, Isd 22, Isd 29, Isd 34 Isd 35 Isd 36 and Isd 38 varieties were also cultivated very negligible $\%$ of farmers (Table-4).

Table 4. Percentage of Farmers cultivating different varieties of sugarcane.

\begin{tabular}{ll}
\hline Variety & $\begin{array}{l}\text { Farmers (\%) cultivating } \\
\text { sugarcane }\end{array}$ \\
\hline Isd 37 & 81.82 \\
Isd 21 & 40.91 \\
Isd 26 & 27.27 \\
Isd 33 & 13.36 \\
Isd 39 & 13.36 \\
Others varieties (Isd 12, Isd 22, Isd & Cultivated by negligible\% of \\
29, Isd 34 Isd 35 Isd 36 and Isd 34) & farmers \\
\hline
\end{tabular}

\subsection{Percentages of Sugarcane Farmers Cultivate Relay Crop}

It was seen that $100 \%$ farmers cultivate relay crops after harvesting of sugarcane and when sugarcanes were very young. However, highest $63.63 \%$ farmers cultivate chili $(63.63 \%)$ as relay crop followed by potato $(54.54 \%)$, tomato $(18.18 \%)$ and cucumber $(13.63 \%)$. Moreover, very minor $\%$ farmers $(4.45 \%$ farmers) were also cultivated onion, tobacco, mustard, coriander, and mung bean (Table - 5) as relay crop.

Table 5. Percentages of sugarcane farmers cultivate relay crop.

\begin{tabular}{ll}
\hline Name of relay crop & Farmer (\%) \\
\hline Chili (Capsicum annuum) & 63.63 \\
Potato (Solanum tuberosum) & 54.54 \\
Tomato (Solanum lycopersicum) & 18.18 \\
Cucumber (Cucumis sativus) & 13.63 \\
Onnion (Allium cepa) & 4.45 \\
Tobacco (Nicotiana tabacum ) & 4.45 \\
Mustard (Brassica juncea) & 4.45 \\
Coriander (Coriandrum sativum) & 4.45 \\
Mung bean (Vigna radiata) & 4.45 \\
\hline
\end{tabular}

Table 6. Categories of famers, loan and benefit information of sugarcane farmers.

\begin{tabular}{|c|c|c|c|c|}
\hline Categories of Farmers & $\begin{array}{l}\text { Those took loan maximum } \\
\text { amount of loan }\end{array}$ & $\begin{array}{l}\text { Those took maximum amount of } \\
\text { land }\end{array}$ & $\begin{array}{l}\text { Farmers benefited } \\
\text { amount of taka }\end{array}$ & $\begin{array}{l}\text { Farmers benefited } \\
\text { amount of taka }\end{array}$ \\
\hline Big Farmers & $\begin{array}{l}\text { Tk.1,95,000/- (average) per } \\
\text { farmer }\end{array}$ & 23 acre land (average) per farmer & Tk.3 lac per farmer & - \\
\hline Medium farmers & Tk.10, 200/- (average) & 3.2 acre land (average) & - & - \\
\hline Small farmers & Tk. 4,000/- & 1 acre acre land (average) & 16 thousands per farmer & - \\
\hline
\end{tabular}

\subsection{Amount of Land and Loan Information}

There is 140.08 hectare (346 acre) of land in Kantagir farm. Farmer leased the entire lands of the adjacent area and cultivates sugarcane. $100 \%$ farmers received loan as seed, fertilizer and insecticides from the sugar mills. Those loans have to pay during the sugarcane by giving all sugarcane to the mills. After paid, if there is extra money, then they returned it from the mills. However, all farmers are benefited as they all are laborious and have no investment without own labour during cultivation and harvesting. So, no need of own land and money except labour for cultivation and harvesting of sugarcane. Farmers could be classified three categories on basis of loan (Table-6) and land such as i) Big Farmers: those took loan maximum Tk.1, 95,000/- (average) loan for cultivation of maximum 23 acre land (average) ii). Medium farmers: those took loan Tk.10, 200/- (average) loan for cultivation of 3.2 acre land (average) iii) Small farmers: those 
took loan Tk. 4,000/- (average) loan for cultivation of 1 acre land (average). However, farmers benefited Tk.3 lac per farmer and minimum 16 thousands per farmer.

\subsection{Problems of Sugarcane Farmers}

Correct identification of any problem makes it easy to solve. Sugarcane farmers were mostly illiterate. So, not all farmers were able to express their problem correctly but those who (a few) somewhat literate expressed their problem very effectively, but their percent was less. Consequently, the problems are summarized as rank (according to the highest $\%$ of farmers claim) wise in table-7.

Table 7. Problems of sugarcane farmers.

\begin{tabular}{ll}
\hline Problems & $\begin{array}{l}\text { Rank (on the basis } \\
\text { of descending \%) }\end{array}$ \\
\hline $\begin{array}{l}\text { Lack of marketing facilities, late purchase of } \\
\text { sugarcane by the sugarcane mill, when it losses its } \\
\text { weight due do dry }\end{array}$ & I \\
$\begin{array}{l}\text { Stem borer insect infestation } \\
\text { Newly adopted tender process taking of land for } \\
\text { sugarcane cultivation instead of leach method }\end{array}$ & II \\
$\begin{array}{l}\text { Have to take loan from the sugarcane mill though } \\
\text { no need of loan }\end{array}$ & IV \\
$\begin{array}{l}\text { Lack of irrigation facilities } \\
\text { Lack of organic manure } \\
\text { No problem }\end{array}$ & V \\
\hline
\end{tabular}

\section{Conclusion}

Sugarcane stem borer is the serious pests of sugarcane; it reduce yield seriously through the boring of stem. This pest is uncontrollable by using insecticides and it a major problem of sugarcane cultivation. So, it is necessary to develop integrated pest management to control the pests. In addition, other main problems of the sugarcane farmers are marketing facilities; the sugarcane mills purchase the sugarcane when it loses its weight due does dry. So, for the save of nation and sugar mills for sugar production as well as supply of sugarcane, the mills would take a suitable process to purchase sugarcane from the farmers in due time.

\section{Acknowledgement}

The authors sincerely acknowledge the "Institute of Research and Training (IRT), Hajee Mohammad Danesh Science and Technology University, Dinajpur, Bangladesh" for its financial supports for the research work.

\section{References}

[1] Ahad, M. A.; Mirtujoy M.; Sardar, M. A. 1987. Krishi Kitbiggan. Ali Press, Mymensingh, Bangladesh.
[2] Ahad, M. A. 2003. Pest management in graminious crops (in Bangla). Bangla Academy, Dhaka, Bangladesh.

[3] Begum, M. K. S.; Islam, M. Abdullah; Alam, M. A. 2005. Estimation of losses caused by major insect pest in some sugarcane clone. Bangladesh J. Sug. 24-27: 70-77.

[4] Ahad, M. A.; H F. El. Taj; M. A. Hossain, 1999. Screening of sugarcane varieties against early shoot borer. Bangladesh J. Training and Dev. 12 (1 \& 2): 49-50.

[5] Avasthy, P. N. 1983. Insect Pest Management for India. In: Sugarcane in Sugarcane Pest Nadu Co-operative Sugar Federation, Madras. pp. 71-77.

[6] Anonymous, 1998. Sugarcane cultivation: Transportable Improve Technology (in Bangla). Bangladesh Sugarcane Research Institute", Ishurdi, Pabna. Publication No. 74.

[7] Yadava, R. I.1991. Sugarcane production technology. IBH publishing Co. Pvt. Ltd., Janapath, New Delhi.

[8] Alam, M. Z. 1967. Insect pest of sugarcane and their control. Proceeding East Pakistan Annual Report.

[9] BSRI, 1970-78. Annual report of "Bangladesh Sugarcane Research Institute", Ishurdi, Pabna.

[10] BSRI. 1992. Annual report of "Bangladesh Sugarcane Research Institute", Ishurdi, Pabna.

[11] Patil, A. S. and D. G. Hapase. 1981. Research on Sugarcane borer in Maharastra Proceedings, National Symposium on stalk borer, Karnal. Pp. 165-175. Indian Sug. 51 (8): 517-520.

[12] Karim, M. A.; Islam, M. N. 1977. Sugarcane insect pests and their natural enemies recorded in Bangladesh. Proceeding Annual convention Bangladesh Society. Seminar on Sugarcane Research and development.

[13] Khanna, K. L. 1957. On the Coccid Melanaspis glomerrata (Green) on sugarcane in Bihar. Indian J. Sug. Res. Dev. (11): 19-22.

[14] Gupta, B. D. 1959. Insect pests of sugarcane in India-V. The shoot borer Chilo infuscatellus Snell. Indian Sug. (9): 445463.

[15] Miah, M. A. H.; Khuda, A. K. M. Q. E.; Alam, M. S.; Biswas, M. M.; Shahjahan, M. 1983. Chemical control of white grubs. Bangladesh J. Sug. (5): 1-7.

[16] Abdullah, M.; Biswas, M. M.; M. A. Alam; M. A. Rahman; Begum, M. 2007. Susceptibility of some promising sugarcane clones to Major Insect pests of sugarcane. Bangladesh J. Sug. (29): 34-41.

[17] Ahad, M. A. and M. A. Haque. 1993. Insect pest attack faced by the farmers in sugarcane cultivation in an area of Bangladesh. Bangladesh J. Exten. Edu. (8): 95-98.

[18] Ahad, M. A.; Hoque M. F. Chowdhury, S. P. and Raja, S. I. 2010. Survey of major insect pests and other problems related to litchi cultivation faced by litchi growers at Dinajpur. Bangladesh J. of Sci. and Tech. 8: 128-134. 